\title{
RECEIVED
}

\section{JAN 301996 \\ Pore Solution Chemistry of Simulated Low-Level Liquid Waste Incorporated in Cement Grouts}

\author{
DISCLAIMER
}

This report was prepared as an account of work sponsored by an agency of the United States Government. Neither the United States Government nor any agency thereof, nor any of their employees, makes any warranty, express or implied, or assumes any legal liability or responsibility for the accuracy, completeness, or usefulness of any information, apparatus, product, or process disclosed, or represents that its use would not infringe privately owned rights. Reference herein to any specific commercial product, process, or service by trade name, trademark, manufacturer, or otherwise does not necessarily constitute or imply its endorsement, recommendation, or favoring by the United States Government or any agency thereof. The views and opinions of authors expressed herein do not necessarily state or reflect those of the United States Government or any agency thereof.

Prepared for the U.S. Department of Energy

Office of Environmental Restoration and

Waste Management

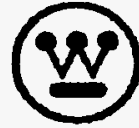

Hanford Operations and Engineering Contractor for the

U.S. Department of Energy under Contract DE-ACO6-87RL10930

Copyright License By acceptance of this article, the publisher and/or recipient acknowledges the

U.S. Government's right to retain a nonexclusive, royelty-free license in and to any copyright covering this paper. 


\section{Pore Solution Chemistry of Simulated Low-Level Liquid Waste Incorporated in Cement Grouts}

A. A. Kruger

Date Published

December 1995

Presented at

1995 Fall Meeting of the Materials Research Society

Boston, Massachusetts

November 27-December 1, 1995

Prepared for the U.S. Department of Energy Office of Environmental Restoration and Waste Management

$\begin{array}{ll}\text { Westinghouse } & \text { P.O Box } 1970 \\ \text { Hanford Company } & \text { Richland, Washington }\end{array}$

Hanford Operations and Engineering Contractor for the U.S. Department of Energy under Contract DE-AC06-87RL10930

Copyright License By acceptance of this article, the publisher and/or recipient acknowledges the U.S. Government's right to retain a nonexclusive, royalty-free license in and to any copyright covering this paper. 
LEGAL DISCLAIMER

This report was prepared as an account of work sponsored by an agency of the United States Government. Neither the United States Government nor any agency thereof, nor any of their employees, nor any of their contractors, subcontractors or their employees, makes any warranty, express or implied, or assumes any legal liability or responsibility for the accuracy, completeness, or any third party's use or the results of sich use of any information, apparatus, product, or process disclosed, or represents that its use would not infringe privately owned rights. Reference herein to any specific commercial product, process, or service by trade name, trademark, manufacturer, or otherwise, does not necessarily constitute or imply its endorsement, recommendation, or favoring by the United States Government or any agency thereof or its contractors or subcontractors. The views and opinions of authors expressed herein do not necessarily state or reflect those of the United States Government or any agency thareof.

This report has been reproduced from the best available copy.

Printed in the United States of America

DISCLM-2.CHP (1-91) 


\section{PORE SOLUTION CHEMISTRY OF SIMULATED LOW LEVEL LIQUID WASTE INCORPORATED CEMENT GROUTS}

Sadananda Sahu and Sidney Diamond

School of Civil Engineering, Purdue University, West Lafayette, IN 47907

sahu@ecn.purdue.edu and diamond@ecn.purdue.edu

\section{ABSTRACT}

Expressed pore solutions from simulated low level liquid waste cement grouts cured at room temperature, $50^{\circ} \mathrm{C}$ and $90^{\circ} \mathrm{C}$ for various duration were analyzed by standard chemical methods and ion chromatography. The solid portions of the grouts were formulated with portland cement, fly ash, slag, and attapulgite clay in the ratios of 3:3:3:1. Two different solutions simulating off-gas condensates expected from vitrification of Hanford low level tank wastes were made. One is highly alkaline and contains the species $\mathrm{Na}^{+}, \mathrm{PO}_{4}{ }^{3-}, \mathrm{NO}_{2}^{-}, \mathrm{NO}_{3}^{-}$and $\mathrm{OH}^{-}$. The other is carbonated and contains the species $\mathrm{Na}^{+}, \mathrm{PO}_{4}{ }^{3-}, \mathrm{NO}_{2}{ }^{-}, \mathrm{NO}_{3}{ }^{-}$, and $\mathrm{CO}_{3}{ }^{2-}$. In both cases phosphate rapidly disappeared from the pore solution, leaving behind sodium in the form of hydroxide. The carbonates were also removed from the pore solution to form calcium carbonate and possibly calcium monocarboaluminate. These reactions resulted in the increase of hydroxide ion concentration in the early period. Subsequently there was a significant reduction $\mathrm{OH}^{-}$and $\mathrm{Na}^{+}$ion concentrations. In contrast high concentration of $\mathrm{NO}_{2}{ }^{-}$and $\mathrm{NO}_{3}{ }^{-}$were retained in the pore solution indefinitely.

\section{INTRODUCTION}

Radioactive waste management has drawn serious attention by the scientific community in recent times. It has been realized that there is a need to immobilize the radionuclides as well as hazardous chemical species before the final disposal.

Blends of various cementitious materials constitute a potential host matrix to immobilize most of the chemical species [1-4]. Solidification of low level liquid waste in cementitious grouts has certain inherent advantages over other methods. Hydrated products may be formed by the participation of some of the waste chemical species in the hydration process; some species may be absorbed in the several hydrated compounds formed, and a significant amount of liquid containing soluble salts can be restrained and rendered somewhat immobile in the highly torturous porous network formed in the hardened grout.

Traditionally the long term performance of cement waste forms are tested by examining their leaching behavior. This is sometimes misleading due to imperfect simulation of conditions that actually exist at the disposal site. Pore solution study, especially at early ages, is an alternative supplementary method to help assess the long term performance of the grout, and the mobility of different waste species in the system. In this study we have examined the behavior of a particular cementitious blend containing attapulgite clay to the two different type of simulated off-gas waste condensate solutions expected to be generated during a proposed vitrification treatment process to be applied to Hanford tank wastes. 
The materials incorporated in the cementitious blend used in this study are a Type I/II portland cement (Ash Grove Cement Co., Durkee, OR), a Class F fly ash (Centralia, WA, purchased from Ross Sand and Gravel Co., Portland, OR), a granulated blast furnace slag (Koch Minerals Co., Chicago, IL), and attapulgite clay (Engelhard Co., Iselin, NJ). The chemical composition of the materials, as provided by their respective suppliers, are given Table I.

Table I. Chemical composition of the raw materials

\begin{tabular}{|c|c|c|c|c|}
\hline Oxides & Cement & Fly ash & Slag & Clay \\
\hline $\mathrm{SiO}_{2}$ & 22.17 & 46.13 & 37.0 & 59.71 \\
\hline $\mathrm{Al}_{2} \mathrm{O}_{3}$ & 3.24 & 25.02 & 8.0 & 9.05 \\
\hline $\mathrm{Fe}_{2} \mathrm{O}_{3}$ & 4.24 & 7.25 & 0.2 & 3.17 \\
\hline $\mathrm{CaO}$ & 64.48 & 8.02 & 39.0 & 3.13 \\
\hline $\mathrm{MgO}$ & 1.13 & 1.81 & 11.0 & 11.21 \\
\hline $\mathrm{K}_{2} \mathrm{O}$ & 0.52 & 0.63 & 0.4 & 0.83 \\
\hline $\mathrm{Na}_{2} \mathrm{O}$ & 0.15 & 4.74 & 0.3 & 0.07 \\
\hline $\mathrm{TiO}_{2}$ & 0.23 & 4.70 & 0.4 & 0.42 \\
\hline $\mathrm{P}_{2} \mathrm{O}_{5}$ & 0.12 & 0.42 & 0.01 & 1.47 \\
\hline $\mathrm{MnO}_{\mathrm{SOO}}$ & 0.06 & 0.03 & 0.5 & 0.05 \\
\hline $\mathrm{SO}_{3}$ & 2.14 & 0.12 & 2.8 & $<0.1$ \\
\hline $\mathrm{LOI}^{\circ}$ & 1.20 & 0.53 & 0.48 & 10.64 \\
\hline
\end{tabular}

The solid blend used as the base of the grouts studied was blended in weight proportions of 3:3:3:1 respectively of cement, fly ash, slag, and attapulgite clay. The dry components were first mixed manually for a prolonged period by stirring and further homogenized in a rotary drum overnight.

So-called "Case 2" (alkaline) and "Case 3" (carbonated) simulated off-gas solutions were prepared from the $A R$ grade laboratory reagents at $45^{\circ} \mathrm{C}$, in order to avoid precipitation of phosphate. The ionic concentrations of the simulated off-gas solutions are given in Table II. "Case 1" solution, which is acidic in nature and prone to produce gases during the grout hydration process, has not been considered.

The grouts were prepared at $45^{\circ} \mathrm{C}$ with a volume to weight, waste/solid ratio of 1 , using a Hobart mixer at the lowest speed. The mixed slurry was poured into many replicate $100 \mathrm{cc}$ plastic ointment jars and sealed in order to avoid any water loss due to evaporation. They were than allowed to react isothermally at room temperature $\left(22^{\circ} \mathrm{C}\right), 50^{\circ} \mathrm{C}$ or at $90^{\circ} \mathrm{C}$. During the grouting process a large amount of exothermic heat is generated due the reaction of cementitious materials with the simulated waste solutions. Furthermore, in handling the real wastes an additional contribution to heating is expected from radiolytic heat generation $[5,6]$. Consequently it is expected that the actual grouts will remain at elevated temperatures in the underground vaults for extended period of time. Isothermal calorimetric study of similar grouts showed that the temperature may rise to as much as $70^{\circ} \mathrm{C}$ with in 3 days and stabilizes at this temperature for an extended period (7). The present high-temperature exposures were employed to gain insight into the responses to be expected under such elevated temperature storage conditions. 
Pore solutions from individual replicate specimens exposed at each temperature were expressed at $12 \mathrm{hrs}$, and at 1,3, 7, 28 and 90 days, according to the procedure described previously [8].

Table II. Ionic Concentration of simulated off-gas solutions

\begin{tabular}{||c|c|c||}
\hline Ionic Species & Case 2, $\mathrm{mM}$ & Case 3, mM \\
\hline $\mathrm{Na}^{+}$ & 1430 & 1508 \\
\hline $\mathrm{PO}_{4}{ }^{3-}$ & 65 & 65 \\
\hline $\mathrm{NO}_{2}^{-}$ & 176 & 176 \\
\hline $\mathrm{NO}_{3}^{-}$ & 385 & 385 \\
\hline $\mathrm{OH}^{-}$ & 672 & - \\
\hline $\mathrm{CO}_{3}{ }^{2-}$ & - & 377 \\
\hline
\end{tabular}

The pore solutions were analyzed for the following ions: $\mathrm{Na}^{+}, \mathrm{K}^{+}, \mathrm{NO}_{2}^{-}, \mathrm{NO}_{3}{ }^{-}, \mathrm{SO}_{4}{ }^{2-}, \mathrm{PO}_{4}{ }^{3-}$ and $\mathrm{OH}^{-}$. The cations were analyzed by atomic absorption spectroscopy and the anions (except $\mathrm{OH}^{-}$) by ion chromatography. The $\mathrm{OH}^{-}$ion concentration was determined by titration with $\mathrm{HCl}$.

\section{RESULTS AND DISCUSSION}

The ionic concentrations of the pore fluids expressed from Case 2 and Case 3 waste forms at various ages up to 90 days at room temperature are presented in Figures 1 (a) and (b) respectively. A comparison of the results for the different ionic species in the two cases show that similar trends are displayed in the both.

Specifically, it was observed that the phosphate was entirely removed from the pore solution before $12 \mathrm{hrs}$ in both cases. The removal of phosphate during the early hours of reaction led to an increase in $\mathrm{OH}^{-}$ion concentration in both the cases.

The Case 3 waste form results indicated that carbonate was removed from the pore solution to precipitate calcium carbonate and the calcium monocarboaluminate phase [9]. These two reactions appeared to result in increases in the $\mathrm{OH}^{-}$ion concentration to a level approximately equivalent to that found for Case 2 waste form.

In both cases the early reduction of sodium ion concentration was significant, with the process continuing but becoming very slow after 7 days.

The $\mathrm{NO}_{2}{ }^{-}$and $\mathrm{NO}_{3}{ }^{-}$concentrations remained high throughout, indicating that these species are not immobilized in the present systems. These results contrasted strongly with reports concerning an alternate cementitious grout blend that incorporated a high volume of fly ash, and where the simulated waste solution was much more alkaline. In those circumstances zeolite was formed in situ, and especially at higher temperature significant amounts of $\mathrm{NO}_{2}^{-}$and $\mathrm{NO}_{3}^{-}$were immobilized [10-12].

The other ions, mainly those released from the cement in early hydration period (e.g. $\mathrm{K}^{+}$ and $\mathrm{SO}_{4}{ }^{2-}$ ) remain in the pore solution indefinitely. 


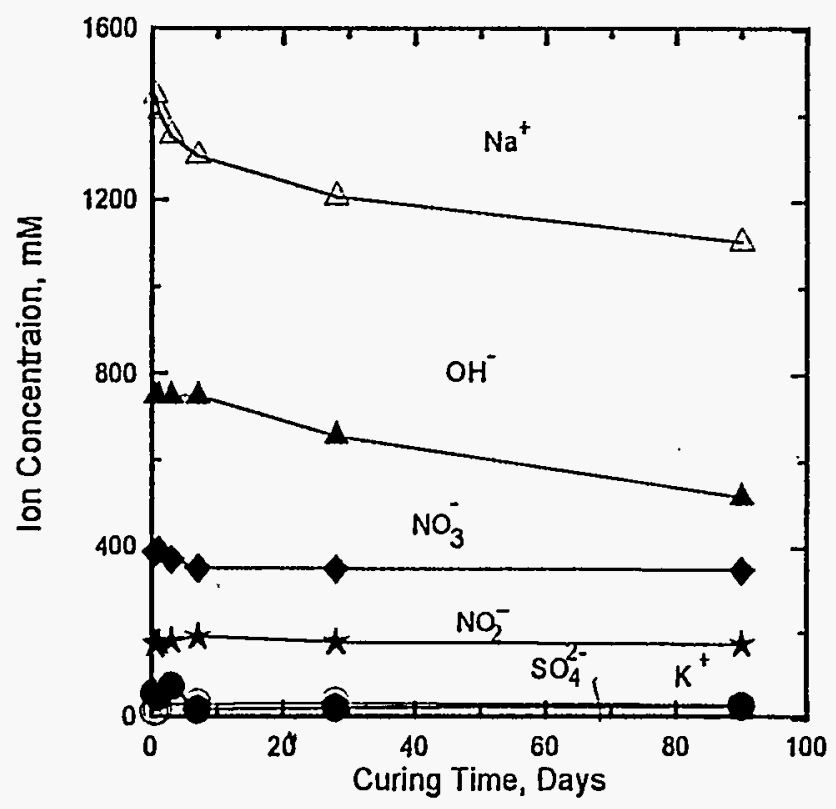

(a) $3: 3: 3: 1 /$ Case 2

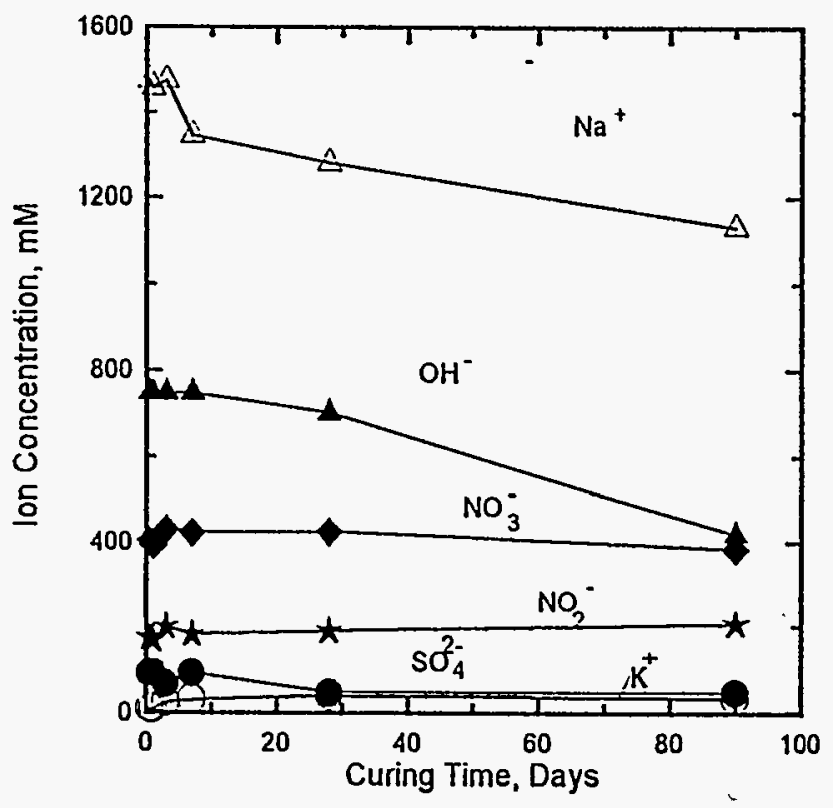

(b) $3: 3: 3: 1 /$ Case 3

Figure 1. Ionic concentrations of pore solutions of simulated off-gas waste forms at room temperature $\left(22^{\circ} \mathrm{C}\right)$

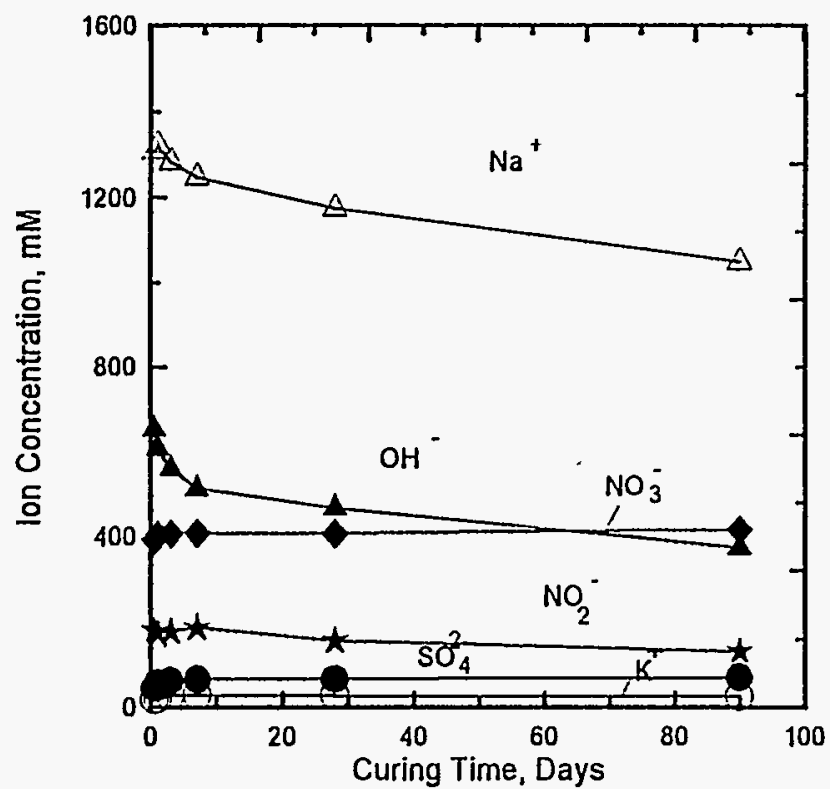

(a) $3: 3: 3: 1 /$ Case 2

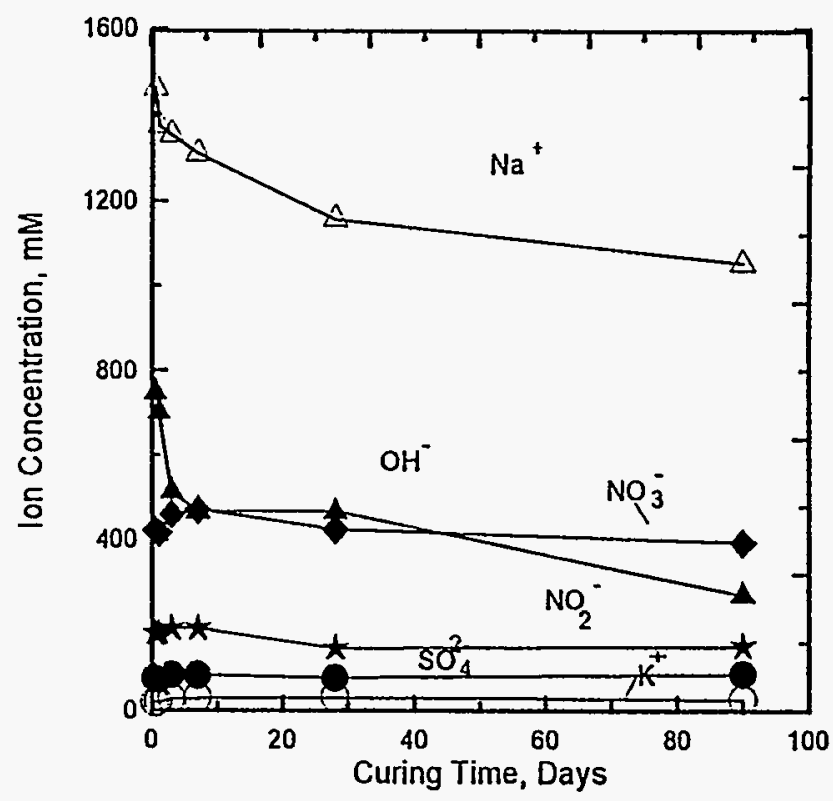

(b) $3: 3: 3: 1 /$ Case 3

Figure 2. Ionic concentrations of pore solutions of simulated off-gas waste forms $\left(50^{\circ} \mathrm{C}\right)$ 


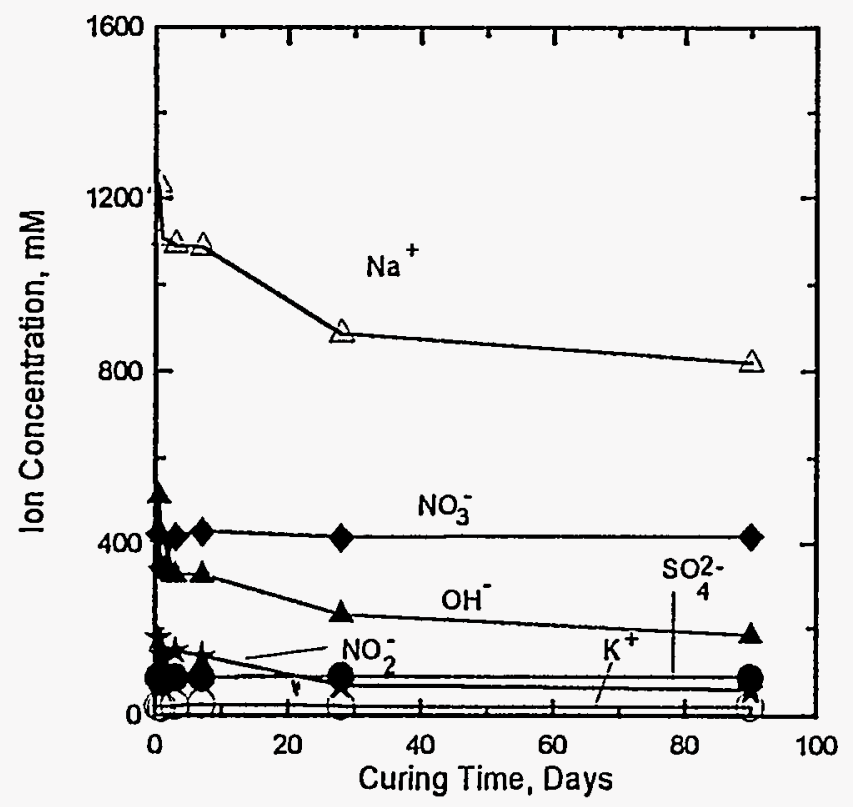

(a) $3: 3: 3: 1 /$ Case 2

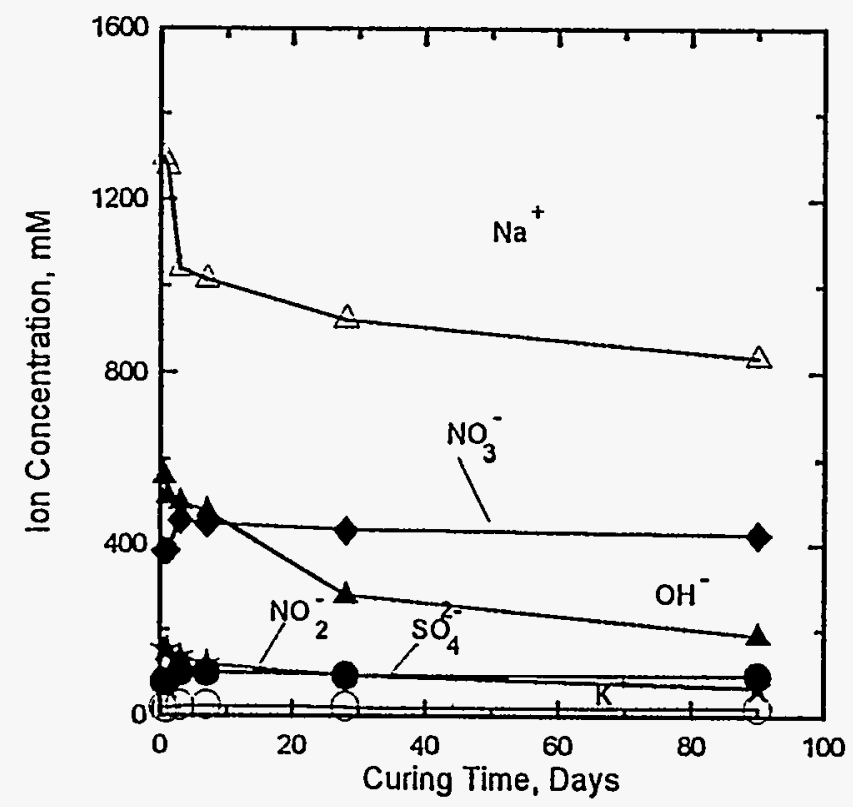

(b) $3: 3: 3: 1 /$ Case 3

Figure 3. Ionic concentrations of pore solutions of simulated off-gas waste forms $\left(90^{\circ} \mathrm{C}\right)$

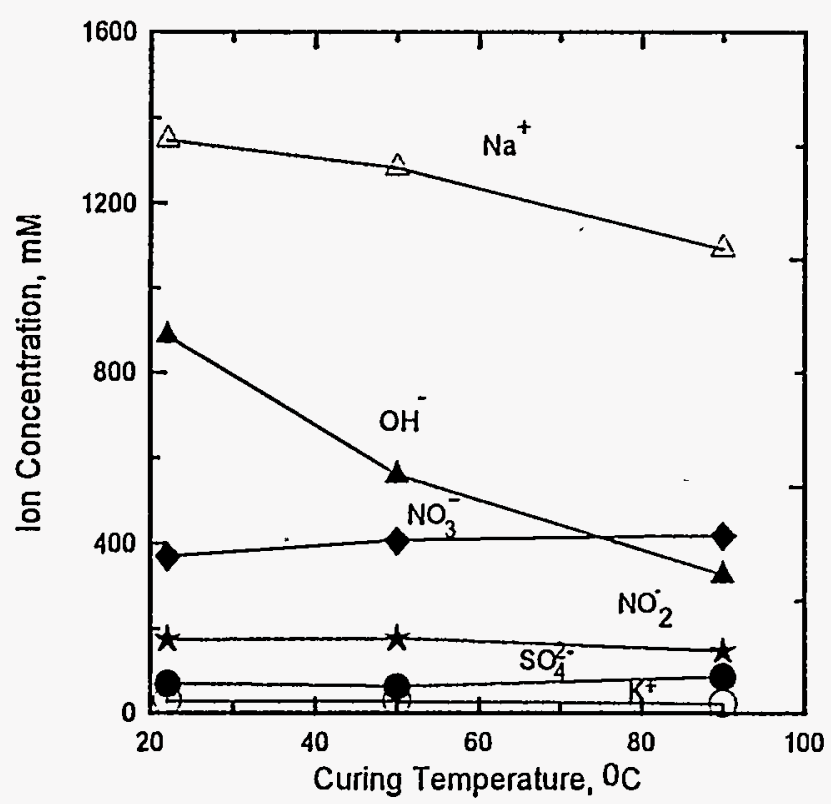

(a) $3: 3: 3: 1 /$ Case 2

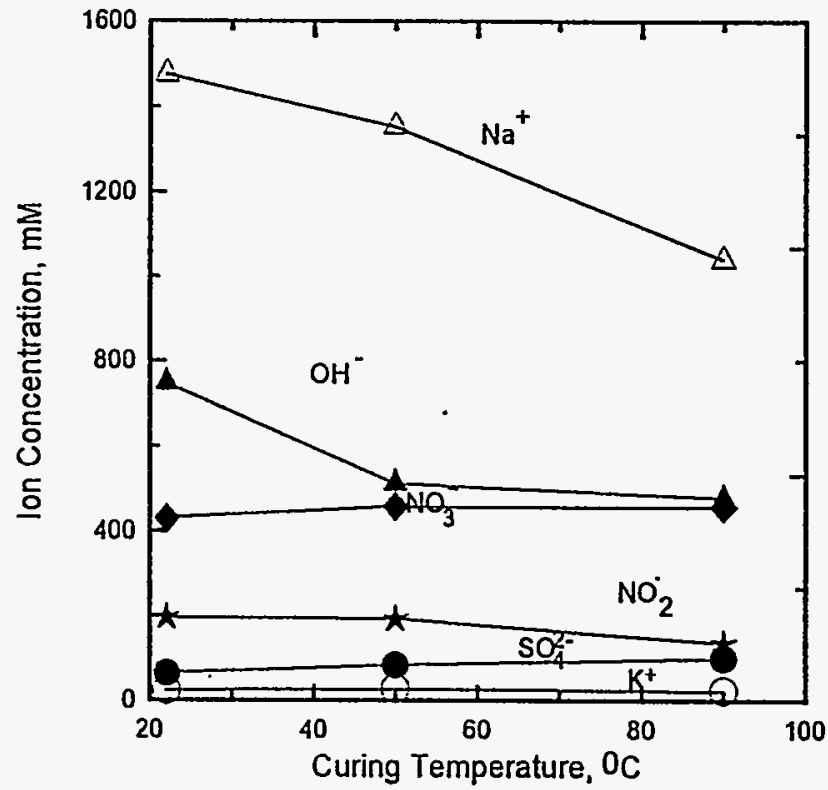

(b) $3: 3: 3: 1 /$ Case 3

Figure 4. Ionic concentrations of pore solutions of simulated off-gas waste forms (3 days curing) 


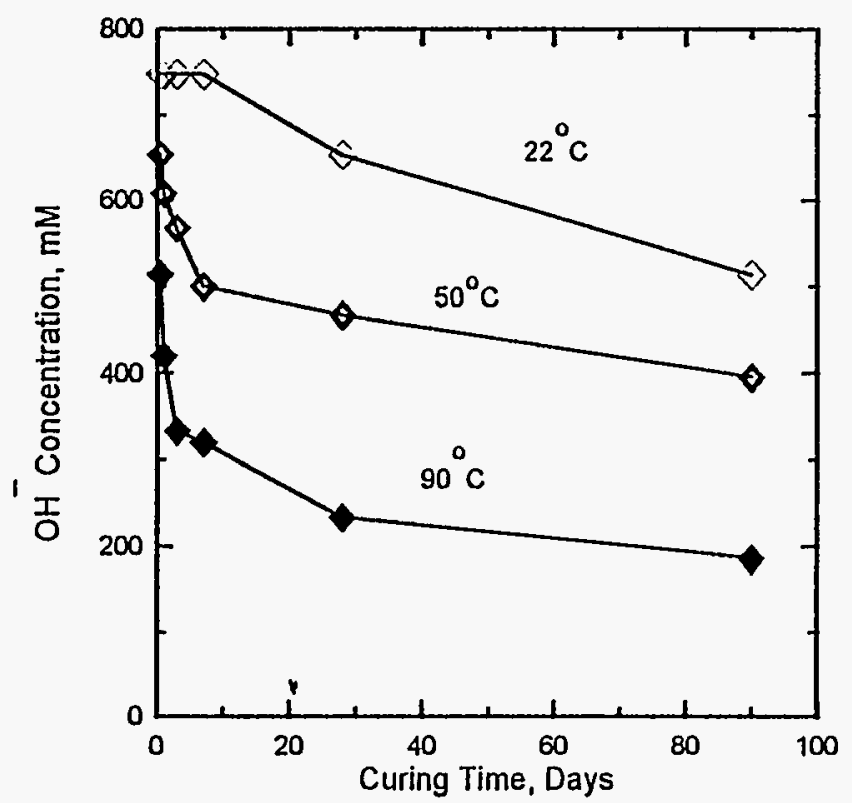

(a) $3: 3: 3: 1 /$ Case 2

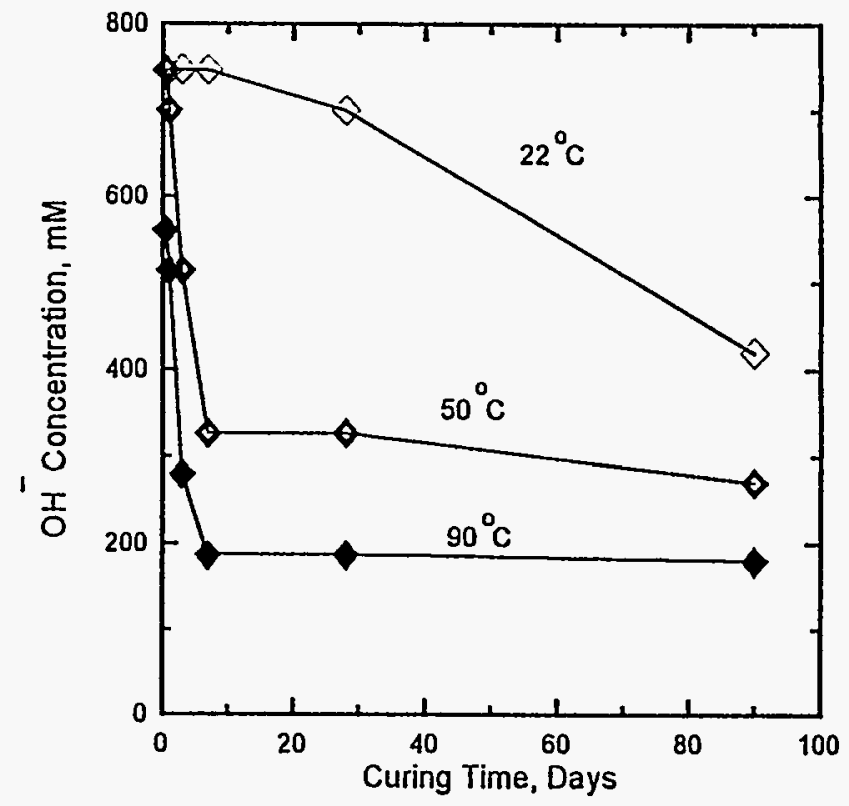

(b) $3: 3: 3: 1 /$ Case 3

Figure 5. Concentrations of $\mathrm{OH}^{-}$ions in the pore solutions of simulated off-gas waste forms, as functions of time and temperature

The ionic concentrations derived from grout exposure at $50^{\circ} \mathrm{C}$ and $90^{\circ} \mathrm{C}$ are presented in Figure 2 and 3 respectively. At higher temperature the reductions in the concentration of $\mathrm{Na}^{+}$and $\mathrm{OH}^{-}$ions takes place more rapidly. Only a small change in $\mathrm{NO}_{2}{ }^{-}$and $\mathrm{NO}_{3}{ }^{-}$ion concentration was observed within 7 days, and thereafter they remained in the pore solution indefinitely.

In Figure 4 (a) and (b) we show the influence of temperature on the concentrations of various chemical species present in the pore solutions at 3 days for Case 2 and Case 3 grouts. Though Case 2 condensate was highly alkaline and the Case 3 condensate was carbonated, their immobilization behavior is seen to be almost similar.

At $90^{\circ} \mathrm{C}$ there was a much stronger reduction in $\mathrm{Na}^{+}$and $\mathrm{OH}^{-}$ion concentrations in both cases than there was at room temperature. At higher temperatures there was a slight decrease in nitrite concentration and corresponding increase in nitrate concentration; most probably due to slow oxidation of nitrite to nitrate. There was a slight increase in concentrations of both $\mathrm{K}^{+}$and $\mathrm{SO}_{4}{ }^{2-}$ ions with temperature. In these systems the main source of these ions is the cement, and at $90^{\circ} \mathrm{C}$ the ions are released faster to the pore solution.

A more detailed examination $\mathrm{OH}^{-}$ion concentrations at all temperatures is given in Figure 5. Again both Cases yielded quite similar results. At room temperature the decrease in $\mathrm{OH}^{-}$ concentration up to 7 days was similar for the two cases, but the reduction was found to continue for longer periods in the Case 3 waste form. At and above $50^{\circ} \mathrm{C}$ most of the decrease in $\mathrm{OH}^{-}$ 
concentration occurred during the first 7 days; subsequent reduction was limited. At $90^{\circ} \mathrm{C}$ after 90 days of hydration the $\mathrm{OH}^{-}$concentration in both the cases reached an identical value.

In both waste forms bleeding at early stages of hydration was a common problem, but generally higher amounts bleeding was observed with the Case 3 solution. A comparison of analyses for the separated bleed water (which remained in contact with hardened grout until removed) and expressed pore solution of 3 days old samples was made for samples hydrated at all three temperatures. It was found the variations in the ionic concentrations with temperature in the bleed water were found to closely match the corresponding data for the pore solutions as shown in Figure 4. This result indicates that at this early ages there is a free exchange of ionic species between the pore solution and bleed water.

\section{CONCLUSIONS}

The following conclusions were drawn from the present study.

1. In both Case 2 and Case 3 grouts all phosphate is removed from the pore solution with in a few hours.

2. The high initial concentration of dissolved carbonate in Case 3 grouts is rapidly removed from the pore solution, creating a solution environment similar to that present in the Case 2 grouts.

3. After a few hours of reaction there is a significant increase in $\mathrm{OH}^{-}$ion concentrations, but subsequently some $\mathrm{Na}^{+}$and $\mathrm{OH}^{-}$ions are removed from solution.

4. At higher temperatures significant additional amounts of $\mathrm{Na}^{+}$and $\mathrm{OH}^{-}$ions are removed from the pore solution.

5. Only a small amount of $\mathrm{NO}_{2}{ }^{-}$is fixed or oxidized in the system leaving behind essentially all of the $\mathrm{NO}_{3}{ }^{-}$and most of the $\mathrm{NO}_{2}^{-}$ions in solution indefinitely.

\section{ACKNOWLEDGMENT}

This work was supported by the grant MTS-SVV-097600 from the Westinghouse Hanford Company.

\section{REFERENCES}

1. K. Brodersen, K. Berghman, F. P. Glasser, N. Longomazino, J. C. Nomine, and J. Wang, Radioactive Waste Management and Disposal, edited by L. Ceclle, (Elsevier Applied Sciences, Amsterdam, 1991), p. 242.

2. D. E. Macphee and F. P. Glasser, Mater. Res. Soc. Bull., 18(3), p. 66 (1993).

3. D. E. Macphee, M. Atkins and F. P. Glasser in Scientific Basis for Nuclear Waste Management XII, edited by W. Lutze and R. C. Ewing (Mater. Res. Soc. Proc. 127, Pittsburgh, PA, 1989), p. 475.

4. M. Atkins and F. P. Glasser, Waste Management 12, p. 105 (1992).

5. R. O. Lokken, J. W. Shade, and F. C. Martin in Scientific Basis for Nuclear Waste Management XIII, edited by W. Lutze and R. C. Ewing (Mater. Res. Soc. Proc. 176, Pittsburgh, PA, 1990), p. 23. 
6. H. L. Benny, "Disposing of liquid low level radioactive tank wastes, Hanford site grout treatment facility" Concrete International, p. 14, July (1990).

7. T. Bakharev, A. R. Brough, private communication.

8. R. S. Barneyback, Jr. and S. Diamond, Cem. and Concr. Res. 11, p. 279 (1981).

9. D. Bonen, et al." Solidification/stabilization of simulated alkaline nonvitrifiable low level radioactive waste by early formation of carbonate bearing AFm phases" in Scientific Basis for Nuclear Waste Management XIX, edited by W. M. Murphy and D. A. Knecht (Mater. Res. Soc. Proc., Pittsburgh, PA, 1996) in press.

10. A. Katz, A. R. Brough, T. Bakharev, R. J. Kirkpatrick, L. J. Struble and J. F. Young in Microstructure of Cement-Based Systems/Bonding and Interfaces in Cementitious Materials, edited by S. Diamond et al. ( Mater. Res. Soc. Proc. 370, Pittsburgh, PA, 1995), p. 209.

11. A. R. Brough, A. Katz, T. Bakharev, G-. K. Sun, R. J. Kirkpatrick, L. J. Struble and J. F. Young in Microstructure of Cement-Based Systems/Bonding and Interfaces in Cementitious Materials, edited by S. Diamond et al. (Mater. Res. Soc. Proc. 370, Pittsburgh, PA, 1995), p. 199.

12. S. Ong and S. Diamond "Pore Solution studies of Simulated Low Level Waste Cement Grouts" presented in 96th Annual Meeting of American Ceramic Society, 1994 (unpublished). 